\title{
COMPARATIVE ANALYSIS OF THE TREND AND FINANCIAL PERFORMANCE OF PRIVATE INDIAN AIRLINES
}

\author{
Chandra Bhowal \\ Master of Commerce
}

\begin{abstract}
Air transport is considered to be the fastest means of transport and so the demand for it has been increasing continuously in India. The present study makes a comparative analysis of the trend of growth and financial performance of two private Indian airline companies during the year 2015-2016 to 2018-2019 on the basis of Trend Percentage and certain ratios viz. Liquidity and Solvency. Two airline company namely, SpiceJet and IndiGo were selected.
\end{abstract}

Keywords: Airline, Liquidity, Solvency, Trend, Aviation

\section{INTRODUCTION}

Indian Airline industry is playing a major role in the development of the country as it provides the facilities of transferring human and other valuable resources globally. It works under the supervision of Ministry of Civil Aviation, Government of India. The Directorate General of Civil Aviation (DGCA) an attached office of the Ministry act as a regulatory body in thesector of Civil Aviation and their major role is to look over all the securities issues, air transport services to/within/from India and also in enforcement of civil air regulations in the country.

Aviation industry in India has become one of the fastest developing sector of the country during the last few years and has became the $3^{\text {rd }}$ largest domestic aviation market in the world and within 2024 it is expected that it will overtake UK to become $3^{\text {rd }}$ largest market for air passenger.

Government of India, in order to meet the growing demand of the passenger planning to raise the number of airports to 250 by 2030(ibef report 2017). Since it is not possible for the government alone to develop the sector, they are trying to encourage private participation by simultaneously increasing FDI upto 49\%. So, the fully government dominated sector is now running parallel to private players.

\section{REVIEW OF LITERATURE}

Dayi et al., (2017) concluded from their study that Air Berlin Group and Thomas Cook Group have the highest loss in implementation whereas it was also seen that the Lufthansa and Turkish Airlines had the successful performance. Phukon et al., (2019), in their study found that the performance of Jet Airways and Air India improved whereas the performance of Kingfisher Airlines had deteriorated due to merger. Suhardjanto et al., (2017), concluded that foreign and government ownership had positive effect on financial performance of airlines whereas no effect had been seen in case of institutional ownership. Jomo et al., (2017), found that all the variables of the study had a positive impact on the profitability of airlines in the aviation industry in Kenya. Teker et al., (2016), in their study made a conclusion that Delta Airlines is the biggest airlines in terms of assets size, whereas, the highest in term of revenue generation was by Luftansa. Hazarika et al., (2016), made a conclusion that Air Arabia is relatively in a better position in terms of profitability and liquidity. Satpathy et al., (2017), from their study found that the top players in this sector was indigo followed by JetAirways. Bharath (2017), concluded that the Indigo Airlines was performing well in terms of different parameters used in the study.

\section{OJECTIVES OF THE STUDY}

1. To have an overview of SpiceJet and Indigo Airline.

2. To study about the financial trend of the selected private airline company. 
3. To analyze the liquidity and solvency position of the selected private airline companies of India.

\section{RESEARCH METHODOLOGY}

The present study is based on secondary data sources mainly collected from annual report of SpiceJet and IndiGo Airline. For the purpose of analysis various ratios were collected and a few statistical methods were also been used. The study is conducted on two airline industry operating in India during the period of 2015-2016 to 2018-2019.

\section{DATA ANALYSIS AND INTERPRETATION}

Table-1: Profile of the Airline Company.

\begin{tabular}{|c|c|c|c|c|}
\hline $\begin{array}{l}\text { NAM } \\
\text { E }\end{array}$ & $\begin{array}{l}\text { LOG } \\
\text { O }\end{array}$ & $\begin{array}{l}\text { YEAR } \\
\text { OF } \\
\text { ESTAB } \\
\text { LISHM } \\
\text { ENT }\end{array}$ & $\begin{array}{l}\text { HEADQU } \\
\text { A-RTERS }\end{array}$ & $\begin{array}{l}\text { MAR } \\
\text { KET } \\
\text { SHA } \\
\text { RE } \\
\text { (MA } \\
\text { Y } \\
\text { 2019) }\end{array}$ \\
\hline $\begin{array}{l}\text { SpiceJ } \\
\text { et }\end{array}$ & ons spicelet & 2004 & $\begin{array}{l}\text { Gurgaon, } \\
\text { India }\end{array}$ & $\begin{array}{l}13.1 \\
\%\end{array}$ \\
\hline IndiGo & $\begin{array}{c}7 \\
\text { IndiGo }\end{array}$ & 2006 & $\begin{array}{l}\text { Gurgaon, } \\
\text { Haryana, } \\
\text { India }\end{array}$ & $\begin{array}{l}49.9 \\
\%\end{array}$ \\
\hline
\end{tabular}

Table-2: Debt Equity Ratio of Selected Airline Companies.

\begin{tabular}{|l|l|l|}
\hline YEAR & SpiceJet & IndiGo \\
\hline $2014-2015$ & 2.19 & 8.06 \\
\hline $2015-2016$ & 2.10 & 2.28 \\
\hline $2016-2017$ & 1.89 & 1.76 \\
\hline $2017-2018$ & 0.61 & 1.12 \\
\hline $2018-2019$ & 0.95 & 1.45 \\
\hline Average & 1.55 & 2.93 \\
\hline $\begin{array}{l}\text { Standard } \\
\text { Deviation }\end{array}$ & 0.72 & 2.90 \\
\hline
\end{tabular}

Source: Annual Report 2016-17, 2017-18 and 2018-19

Interpretation: Table- 2 reveals the debt equity ratio of two select airline companies namely, SpiceJet and IndiGo. The average debt equity ratio is found lowest in case of SpiceJet, which means the company is more secure in meeting the obligations to creditors. The value of Standard Deviation is also found lowest in case of SpiceJet while it value is highest in case of IndiGo. Thus, the value of Standard Deviation of debt equity ratio suggests that the volatility is maximum in the capital structure of IndiGo while consistency has been most pronounced in the capital structure of SpiceJet.

Table-3: Total Assets to Debt Ratio of Selected Ailine Companies.

\begin{tabular}{|c|c|c|}
\hline YEAR & SpiceJet & IndiGo \\
\hline 2014-2015 & 2.06 & 1.64 \\
\hline $2015-2016$ & 2.26 & 2.03 \\
\hline $2016-2017$ & 2.64 & 2.29 \\
\hline $2017-2018$ & 4.12 & 2.66 \\
\hline $2018-2019$ & 3.15 & 2.48 \\
\hline Average & 2.85 & 2.22 \\
\hline $\begin{array}{l}\text { Standard } \\
\text { Deviation }\end{array}$ & 0.82 & 0.40 \\
\hline
\end{tabular}

Interpretation: Table- 3 reveals the total assets to debt ratio of SpiceJet and IndiGo airline companies. The average total assets to debt ratio are highest in case of SpiceJet and the same ratio is found to be lowest in case of IndiGo, which means the coverage of external debts is greater in case of SpiceJet. The value of Standard Deviation shows more consistency in favour of SpiceJet as it is found to be lowest with compare to IndiGo.

Table-4: Capital Employed to Total Assets Ratio of Selected Airline Companies.

\begin{tabular}{|l|l|l|}
\hline YEAR & SPICEJET & INDIGO \\
\hline $2014-2015$ & 0.22 & 0.08 \\
\hline $2015-2016$ & 0.21 & 0.22 \\
\hline $2016-2017$ & 0.20 & 0.25 \\
\hline $2017-2018$ & 0.40 & 0.33 \\
\hline $2018-2019$ & 0.33 & 0.28 \\
\hline Average & 0.27 & 0.23 \\
\hline $\begin{array}{l}\text { Standard } \\
\text { Deviation }\end{array}$ & 0.09 & 0.09 \\
\hline
\end{tabular}

Source: Annual Report 2016-17, 2017-18 and 2018-19

Interpretation: Table-4 shows the capital employed to total assets ratio of two selected airline companies. The average is found to be highest in case of SpiceJet and it is lowest in case of IndiGo. It means the security of the creditors is better in case of SpiceJet with compare to IndiGo. The results of Standard Deviation reveal that both the airline companies maintain same proportion with regards to capital employed and total assets.

Table-5: Current Ratio of Selected Airline Companies.

\begin{tabular}{|l|l|l|}
\hline YEAR & SPICEJET & INDIGO \\
\hline $2014-2015$ & 0.19 & 0.97 \\
\hline
\end{tabular}




\begin{tabular}{|l|l|l|}
\hline $2015-2016$ & 0.26 & 1.52 \\
\hline $2016-2017$ & 0.28 & 1.97 \\
\hline $2017-2018$ & 0.30 & 2.39 \\
\hline $2018-2019$ & 0.38 & 2.26 \\
\hline Average & 0.28 & 1.82 \\
\hline $\begin{array}{l}\text { Standard } \\
\text { Deviation }\end{array}$ & 0.07 & 0.58 \\
\hline
\end{tabular}

Source: Annual Report 2016-17, 2017-18 and 2018-19

Interpretation: Table-5 reveals the current ration of two airline companies. The average current ratio is highest in case of IndiGo whereas it is found to be lowest in case of SpiceJet. It means in comparison to SpiceJet, the liquidity position of IndiGo is found better. The result of Standard Deviation is lowest in case of SpiceJet and the same is highest in case of IndiGo. Thus, the value of standard deviation of current ratio suggests that the volatility is maximum in case of IndiGo while consistent in case of IndiGo.

Table-6: Acid Test Ratio of Selected Airline Companies.

\begin{tabular}{|l|l|l|}
\hline YEAR & SpiceJet & IndiGo \\
\hline $2014-2015$ & 0.18 & 0.94 \\
\hline $2015-2016$ & 0.23 & 1.50 \\
\hline $2016-2017$ & 0.25 & 1.94 \\
\hline $2017-2018$ & 0.26 & 2.36 \\
\hline $2018-2019$ & 0.34 & 2.24 \\
\hline Average & 0.25 & 1.8 \\
\hline $\begin{array}{l}\text { Standard } \\
\text { Deviation }\end{array}$ & 0.06 & 0.58 \\
\hline
\end{tabular}

Source: Annual Report 2016-17, 2017-18 and 2018-19

Interpretation: Table- 6 reveals the acid test ratio of two selected airline companies. Average is highest in case of IndiGo, which means the absolute liquidity position of IndiGo is better than the position of SpiceJet. The value of Standard Deviation is highest in case of IndiGo whereas it is found to be lowest in case of SpiceJet. Thus from the result of Standard Deviation we can conclude that there is more consistency over the liquidity position of SpiceJet company.

Comparative Trend Analysis of Both SpiceJet and IndiGo Airline Companies Operating in India:

Table-7: Trend Percentage of SpiceJet Airline Company.

Trend Percentage of SpiceJet

\begin{tabular}{|l|l|}
\hline BASE YEAR & 2015-2016 \\
\hline
\end{tabular}

\begin{tabular}{|l|l|l|l|}
\hline \multirow{2}{*}{ PARTICULARS } & $\begin{array}{l}\text { 2016- } \\
2017\end{array}$ & $\begin{array}{l}\text { 2017- } \\
2018\end{array}$ & $\begin{array}{l}\text { 2018- } \\
\text { 2019 }\end{array}$ \\
\hline
\end{tabular}

\begin{tabular}{|l|l|l|l|}
\hline & $(\mathbf{\% )}$ & $\mathbf{( \% )}$ & $\mathbf{( \% )}$ \\
\hline Inventories & 130.73 & 186.89 & 206.36 \\
\hline Total Assets & 105.07 & 141.62 & 168.44 \\
\hline Total Liabilities & 92.65 & 104.86 & 132.43 \\
\hline Borrowings & 84.26 & 70.68 & 60.44 \\
\hline Total Revenue & 120.16 & 150.13 & 175.73 \\
\hline Total Expenses & 124.12 & 153.79 & 200.48 \\
\hline
\end{tabular}

Source: Annual Report 2016-17, 2017-18 and 2018-19

Interpretation: Table-7 reveals the trend analysis of the SpiceJet airline company for the FY year 2016-2017, 2017-2018 and 2018-2019 respectively, taking Base Year as 2015-2016. From the above analytical result the following conclusion can be drawn:

i) Inventories and Total Assets have shown a continuous increasing trend, it indicates expansion activities undertaken by the company.

ii) Company is also moving towards positive direction as its Total Revenue is showing a steady increase at the same time its Total Liabilities shows a declining trend.

iii) Borrowings of the company shows a decreasing trend, which indicates that the company is moving towards a better position to pay off all its liabilities and expenses by their own.

iv) There is a steady increase of Total Expenses from $124.12 \%$ to $200.48 \%$.

Table-8: Trend Percentage of IndiGo Airline Company.

\begin{tabular}{|c|c|c|c|}
\hline \multicolumn{4}{|c|}{ Trend Percentage of IndiGo } \\
\hline \multirow{2}{*}{$\begin{array}{l}\text { BASE YEAR } \\
\text { PARTICULARS }\end{array}$} & \multicolumn{3}{|c|}{$2015-2016$} \\
\hline & $\begin{array}{l}\text { 2016- } \\
2017 \\
(\%) \\
\end{array}$ & $\begin{array}{l}2017- \\
2018 \\
(\%) \\
\end{array}$ & $\begin{array}{l}2018- \\
2019 \\
(\%) \\
\end{array}$ \\
\hline Inventories & 213.88 & 240.20 & 277.18 \\
\hline Total Assets & 120.53 & 167.44 & 198.21 \\
\hline Total Liabilities & 120.53 & 167.44 & 198.21 \\
\hline Borrowings & 79.67 & 74.54 & 72.95 \\
\hline Total Revenue & 116.30 & 143.91 & 179.06 \\
\hline Total Expenses & 124.54 & 150.68 & 216.68 \\
\hline
\end{tabular}

Interpretation: Table- 8 reveals the trend analysis of the IndiGo airline company for the FY year 2016-2017, 2017-2018 and 2018-2019 respectively, taking Base Year as 2015-2016. From the above analytical result the following conclusion can be drawn: 
i)

Inventories and Total Assets have shown a continuous increasing trend, it indicates expansion activities undertaken by the company.

ii) Company is also moving towards positive direction as its Total Revenue is showing a steady increase at the same time its Total Liabilities also shows a increasing trend.

iii) Borrowings of the company shows a decreasing trend, which indicates that the company is moving towards a better position to pay off all its liabilities and expenses by their own.

iv) There is a steady increase of Total Expenses from $124.54 \%$ to $216.68 \%$.

The position of Inventories and Total Assets in both the companies shown a continuous increasing trend but with comparison to SpiceJet the Inventories position of IndiGo is found to be in a better position and the growth rate is also found higher. Borrowings in both the companies are in its declining trend. The profitability position of both the companies are moving towards positive direction as indicated by the raising Total Revenue trend.

\section{CONCLUSION}

During the period of study, the Solvency position of SpiceJet was found in better position as compare to IndiGo as indicated by Debt-equity ratio, Total Assets to Debt ratio and Capital Employed to Total Assets ratio. Whereas from the Liquidity side it was found that the IndiGo Airline was performing better as revealed by the current ratio and Acid Test ratio. From the trend analysis of two airline companies, it was found that inventories and Total Assets of both the companies shown a continuous increasing motion and the growth percent of inventories of IndiGo is higher than SpiceJet Airline. It was also found during the study that the profitability position of both the selected airline companies is moving towards positive direction.

\section{REFERENCES}

1. Alwiyah, Suhardjanto, D., Jatmiko, \& Ajibroto, N. "Ownership Structure and Financial Performance: An Empirical Study of Listed Airlines Industry in Asia and Australia", Review of Integrative Business and Economics Research, pp. 121-130, 2007.

2. Bharath, K. "COMPARATIVE STUDY ON GROWTH AND FINANCIAL PERFORMANCE OF JET AIRWAYS, INDIGO AIRLINES \& SPICEJET
AIRLINES COMPANIES IN INDIA", ISBR Management Journal, vol. 2, 2017.

3. Dayi, F., \& Esmer, Y. "MEASURING FINANCIAL PERFORMANCE OF AIRLINE PASSENGER TRANSPORT COMPANY IN EUROPEAN", 33rd International Academic Conference (pp. 26-37). Vienna: IISES, 2017.

4. Hazarika, I., \& Boukareva, B. "PERFORMANCE ANALYSIS OF MAJOR AIRLINE COMPANIES IN UAE WITH REFERENCE TO PROFITABILITY, LIQUIDITY, EFFICIENCY, EMPLOYEE STRENGTH AND PRODUCTIVITY", Eurasian Journal of Business and Management, Vol. 4(4), pp. 71-80, 2016.

5. Jomo, E. B., Oloko, M., \& Orwa, G. "Determinants of Profitability of Airlines in the Aviation Industry in Kenya", International Journal of Scientific and Research Publications, Vol. 7, Issue 5, pp. 261-263, 2017.

6. Phukon, A., Konwar, M., \& Gakhar, D. V. "Impact of Mergers and Acquisitions on Financial Performance of Select Airline Companies in India", Journal of Public Administration ,Vol. 1, Issue 1, pp. 37-47, 2019.

7. Satpathy, I., Patnaik, B., \& Kumar, S. "Indian aviation industry: An overview", International Journal of Academic Research and Development , Vol.2, pp.802-805, 2017.

8. Teker, S., Teker, D., \& Guner, A. "Financial Performance of Top 20 Airlines", ELSEVIER , pp. 603-610, 2016.

9. Annual Report of SpiceJet, (2015-16, 2016-17, 2017-18, 2018-19).

10. Annual Report of IndiGo (2015-16, 201617, 2017-18, 2018-19).

11. https://www.ibef.org/industry/indianaviation.aspx

12. http://www.civilaviation.gov.in

13. https://www.spicejet.com

14. https://www.goindigo.in

15. https://www.aai.aero/sites/default/files/pre ss_release_news/PM\%20lays\%20the\%20f oundation \%20stone \%20for \%20extension \%20of\%20terminal\%20building\%20at $\% 2$ OSURAT.pdf 